\title{
A comprehensive view of Intelligent Transport Systems (ITS) for urban Smart Mobility
}

Riccardo Mangiaracina ${ }^{1}$, Alessandro Perego $^{2}$, Giulio Salvadori ${ }^{3}$, Angela Tumino $^{4}$

\author{
1,2,3,4 Department of Management, Economics and Industrial Engineering, Politecnico di \\ Milano, Milano, Italy \\ Via Raffaele Lambruschini, $4 \mathrm{~b}$ \\ 20156 Milan (Italy) \\ ${ }^{1}$ E-mail address: riccardo.mangiaracina@polimi.it \\ ${ }^{2}$ E-mail address: alessandro.perego@polimi.it \\ ${ }^{3}$ Corresponding author. E-mail address: giulio.salvadori@polimi.it \\ Phone: +3902 23999560 \\ ${ }^{4}$ E-mail address: angela.tumino@polimi.it
}




\title{
A comprehensive view of Intelligent Transport Systems (ITS) for urban Smart Mobility
}

\begin{abstract}
Information accuracy and decision-making speed are of paramount importance in managing today's mobility of goods and people inside the city. Intelligent Transport Systems (ITS) can provide road users with updated information and forecasts on both traffic and weather conditions. The result is a higher efficiency in the use of resources and a better management of physical flows. The purpose of this paper is to conduct an in-depth review on the role of ITS supporting urban Smart Mobility, in order to identify the main gaps in the literature and propose future research streams. 71 papers have been thoroughly analysed: they are mainly focused on technology, with limited attention to value creation. Even though some benefits have been examined, a general lack of quantitative models emerged. Eventually, there is a lack of contributions considering both people and freight transport, even if they are strongly related especially in an urban environment.
\end{abstract}

\section{Keywords}

Urban Smart Mobility, Smart City, Intelligent Transport Systems, ITS, People transport, Freight transport 


\section{Introduction}

Urban population is expected to significantly grow in the next decades: from 3.9 billion people that already live in cities (54\% of the whole global population) to 6.3 billion by 2050 (i.e. $66 \%$ ). Today cities are responsible for more than $75 \%$ of waste production, $80 \%$ of emissions, and $75 \%$ of energy utilisation (United Nations 2014). With regard to Europe, road transport produces about $20 \%$ of the total $\mathrm{CO}_{2}$ emissions, of which $40 \%$ is generated by urban mobility (European Commission 2015). Therefore, there is a huge interest in understanding how urban transport can become more sustainable.

Urban mobility includes both freight and people transport. The former considers the movement of vehicles (e.g. trucks, vans) whose primary purpose is to carry goods into, out of and within urban areas. The latter should be split into individual and collective transport. In individual transport the route is the outcome of a personal choice, and the most common travel alternatives are cars, motorbikes, bikes, and walking. Conversely, the purpose of collective transport is to provide public mobility services connecting specific parts of the city. Its efficiency is based upon transporting a large number of people and achieving economies of scale. It includes transport means like tramways, buses, trains, undergrounds and ferryboats. In collective transport the travels are planned by cargo owners and transport service providers. In the current literature, freight and people transport are mainly analysed individually. However, in several instances passengers and freight movements may be competing for the usage of the available transport infrastructures. In urban areas the road is often the only viable alternative for freight transport, and the vehicles have negative effects on the overall traffic situation, the environment and the safety level (Kohler 2001; Patier 2002; Westerheim and Natvig 2008; Crainic, Gendreau and Potvin 2009; Ballantyne, Lindholm and Whiteing 2013). These elements suggest that approaching the issue fragmentarily could not be appropriate anymore (Browne and Allen 2011).

In such a complex environment, Information and Communication Technologies (ICTs) can play a key role in improving transport sustainability through controlling systems more efficiently, facilitating behavioural changes and reducing energy consumption (Bull 2015). 'Intelligent Transport Systems' (ITS) is the most common expression used to indicate the integrated application of ICTs to transport (Miles 2014). ITS can be applied to all modes of transport, i.e. air, ship, rail and road, and to every element of a transport system, i.e. the vehicle, the infrastructure, and the driver or user, interacting together dynamically. The overall function of 
ITS is to support transport network controllers and other users (citizens, companies and city governments) in the decision making process (ITS Handbook 2012), leveraging on accurate real-time information about traffic and vehicle conditions. As a result, the operation of the entire transport system is expected to improve (Miles 2014), leading to a better use of resources and to a more rational coordination of physical flows. ITS can support transport processes in many different ways. For example, one of the simplest and most diffused applications is enabled by data gathered from GPS vehicle tracking systems, which can be used to determine expected travel times and promptly identify traffic jams. More recently, a wide range of new opportunities has been exploited by connecting Vehicles to other Vehicles (V2V) or Vehicles to the road Infrastructure (V2I). V2V solutions mainly impact on safety, thanks to applications like the advanced emergency braking systems. V2I applications could have an important effect also in improving traffic flows (Perakovic 2014, Poslad et al. 2015). For instance, the vehicles can set the most appropriate speed based on the future status communicated by smart traffic lights (i.e. red, yellow, green).

In line with this premise, it is essential to have a clear and comprehensive picture of the potentialities of ITS for both freight and people urban transport. In the current literature there are many fragmented contributions, each one focused on specific topics (e.g. smart traffic lights, parking spot availability, public transport location and management, tracking and tracing of dangerous goods). In order to identify further research directions, a complete picture of the extant body of knowledge should be taken. The existing literature analyses are not up-to-date and complete: none of them has been published recently (i.e. in the last 2 years) and, above all, they are focused on specific fields (e.g. freight transport). The purpose of this paper is twofold: (i) to categorise the research on ITS for urban Smart Mobility according to the main topics addressed and the methods adopted, and (ii) to identify the main literature gaps in order to propose directions for future research activities.

\section{Methodology}

In line with Srivastava (2007) and Mangiaracina et al. (2015), the paper selection process included the following stages:

- Definition of the classification context: it consisted of ITS applications for Smart Mobility considering both people and freight transport;

- Identification of the unit of analysis: papers published on international peer-reviewed journals and proceedings of international conferences were considered. The papers were 
published on the major journals in the fields of urban mobility addressing people and freight transport (e.g. Cities, Environmental Science and Policy, Journal of Systems and Software, Procedia - Social and Behavioral Sciences, Research in Transportation Economics, Sensors, Technology in Society, Transportation Research, Transport Reviews, Wireless Personal Communications, International Journal of Physical Distribution and Logistics Management, International Journal of Logistics Management, International Journal of Logistics Systems and Management) or were included in the most important proceedings of international conferences on urban mobility (e.g. IEEE International Conference on Intelligent Sensors, Sensor Networks and Information Processing, World Congress on Intelligent Transport Systems, Proceedings of International Conference on Advances in Mobile Computing and Multimedia);

- Collection of relevant publications: the search was conducted using a number of keywords (e.g. "Smart urban Mobility", "City Logistics", "Last-mile Logistics”, "traffic congestion”, "parking management”, "Intelligent Transport Systems”, “ITS”, “freight transport", "people transport", "Smart City") and their combinations, coherently selected and in line with the objectives of the analysis. The starting point for the identification of relevant papers was a number of library databases (i.e. Isi Web of Knowledge, Scopus and Google Scholar). For each paper, the abstract, the introduction and the conclusions were carefully examined in order to select the most relevant contributions for the purpose of this review. To avoid the omission of other important papers, the majority of the cited contributions were also cross-referenced and, if necessary, included in the analysis. By applying this method, it was possible to assure adequate coverage of the extant body of research in this field;

- Delimiting the field: during the examination of the papers that were progressively found, some were recognised to be more significant than others for the purposes of the present study. Initially, more than 100 articles were found. Then, those papers addressing the topic summarily or as a collateral research theme were excluded. Consequently, 71 papers published from 2006 to 2015 have been selected to be examined in depth (none of the few papers published before 2006 was considered significant for the purposes of this analysis, since they addressed the topic in a very marginal way). The authors believe that the number of publications reviewed in this study is adequate given the scope of the analysis (i.e. focus on a restricted - although promising - subject), and this is consistent with previous contributions addressing specific research themes (e.g. Perego, Perotti 
and Mangiaracina 2011, Seuring and Gold, 2012).

- Analysis of the selected papers: different methods used in previous literature review papers (e.g. Srivastava 2007; Carter, Kauffman, and Michel 2007; Meixell and Norbis 2008; Ghadge, Dani and Kalawsky 2012; Seuring and Gold 2012; Mangiaracina et al. 2015) were examined first. For the purposes of this review, the 71 selected contributions were analysed and categorised according to the year of publication, the research method adopted, the type of urban transport considered, the type of data analysis and the aims / main topics tackled. All the papers were first summarised and then categorised in accordance with the review criteria, which was also helpful in identifying patterns that suggest interesting themes or possible gaps (Meixell and Norbis 2008).

\section{Summary of review: research methods adopted}

As mentioned before, the selected papers were first classified and examined according to the main research method adopted, namely literature review, simulation, case study, analytical model, benchmarking, survey, and conceptual framework. Moreover, they were also categorised according to the type of data analysis (i.e. qualitative and/or quantitative analyses) and the type of urban transport, i.e. people vs. freight, in order to detect possible relationships with the choice of the method.

Table 1. Classification of each paper by Method, Type of transport and Type of Data analysis

\begin{tabular}{|l|c|c|l|}
\hline \multicolumn{1}{|c|}{$\begin{array}{c}\text { Research } \\
\text { method* }\end{array}$} & $\begin{array}{c}\text { Type of } \\
\text { transport }\end{array}$ & $\begin{array}{c}\text { Type of data } \\
\text { analysis** }\end{array}$ & \multicolumn{1}{c|}{ Papers } \\
\hline \multirow{3}{*}{$\begin{array}{l}\text { Literature } \\
\text { review (8; 11\%) }\end{array}$} & Freight (7) & QAL & Hancke, de Silva and Hancke jr (2013) \\
\cline { 2 - 4 } & QAL & $\begin{array}{l}\text { Benjelloun, Bigras and Crainic (2008), Russo and } \\
\text { Comi (2010), Behrends (2011), Perego, Perotti and } \\
\text { Mangiaracina (2011), Anand et al. (2012), } \\
\text { Mirzabeiki (2013) }\end{array}$ \\
\hline \multirow{2}{*}{$\begin{array}{l}\text { Simulation (15; } \\
21 \%)\end{array}$} & QAN & $\begin{array}{l}\text { Salido, Peinado and Giret (2011), Nha et al. (2012), } \\
\text { Barba et al. (2012), Geng and Cassandras (2012), } \\
\text { Cheng and Li (2013), Galàn-Garcìa, Venegas, and } \\
\text { Cielos (2014), Horng (2014), Poxrucker, Bahle and } \\
\text { Lukowicz (2014), Shin and Jun (2014), Caballero- } \\
\text { Gil, C., Molina-Gil and Caballero-Gil, P. (2015) }\end{array}$ \\
\cline { 2 - 5 } & Freight (5) & QAN & $\begin{array}{l}\text { Aschauer and Starkl (2010), Taniguchi, Thompson } \\
\text { and Yamada (2012), Bhattacharya et al. (2014), } \\
\text { Gevaers, Van de Voorde and Vanelslander (2014), } \\
\text { Nechifor et al. (2015) }\end{array}$ \\
\hline
\end{tabular}




\begin{tabular}{|c|c|c|c|}
\hline \multirow{4}{*}{$\begin{array}{l}\text { Case study (24; } \\
34 \%)\end{array}$} & \multirow{2}{*}{ People (13) } & QAL & $\begin{array}{l}\text { Moniri, Feld and Muller (2012), Das and Emuze } \\
\text { (2014), Ji et al. (2014), Ferrari et al. (2014), Poslad et } \\
\text { al. (2015), Marsal-Llacuna, Colomer-Llina`s and } \\
\text { Mele'ndez-Frigola (2015), Khamitov, Iskakova, and } \\
\text { Khamitova (2015) }\end{array}$ \\
\hline & & QAN & $\begin{array}{l}\text { Liu et al. (2009), Bhoraskar et al. (2012), Fuller et al. } \\
\text { (2012), Smith et al. (2013), Losa, Pratelli and } \\
\text { Riccardi (2014), Simonyi, Fazekas and Gaspar } \\
\text { (2014) }\end{array}$ \\
\hline & \multirow[t]{2}{*}{ Freight (11) } & QAL & $\begin{array}{l}\text { Westerheim and Natvig (2008), Kuse, Endo and Ivao } \\
\text { (2010), Reclus (2013), Diziain, Taniguchi and } \\
\text { Dablanc (2014), De Souza et al. (2014), Van } \\
\text { Leeuwen, Van Eeden, and Ottenhof (2014), Oliveira } \\
\text { et al. (2015) }\end{array}$ \\
\hline & & QAN & $\begin{array}{l}\text { Oliveira, Nunes and Novaes (2010), Van Duin, Quak } \\
\text { and Muñuzuri (2010), De Magalhães (2010), Wang, } \\
\text { Rodrigues and Evans (2015) }\end{array}$ \\
\hline \multirow[t]{2}{*}{$\begin{array}{l}\text { Analytical } \\
\text { model }(10 \\
14 \%)\end{array}$} & People (7) & QAN & $\begin{array}{l}\text { Pérez et al. (2010), Kolosz, Grant-Muller and } \\
\text { Djemame (2013), Kolosz, Grant-Muller and } \\
\text { Djemame (2013), Honarmand, Zakariazadeh, and } \\
\text { Jadid (2014), Neirotti et al. (2014), Zheng, } \\
\text { Rajasegarar and Leckie (2015), Gibson et al. (2015) }\end{array}$ \\
\hline & Freight (3) & QAN & $\begin{array}{l}\text { Kayikci (2010), Gevaers, Van de Voorde and } \\
\text { Vanelslander (2011), Joubert and Meintjes (2015) }\end{array}$ \\
\hline \multirow[b]{2}{*}{$\begin{array}{l}\text { Benchmarking } \\
(5 ; 7 \%)\end{array}$} & People (2) & QAL & Giffinger et al. (2007), Debnath et al. (2014) \\
\hline & Freight (3) & QAL & $\begin{array}{l}\text { Stapleton, Martinez and Van Wassenhove (2009), } \\
\text { Benjelloun, Crainic and Bigras (2010), Taniguchi, } \\
\text { Thompson and Yamada (2010) }\end{array}$ \\
\hline \multirow{3}{*}{ Survey $(7 ; 10 \%)$} & People (3) & QAN & $\begin{array}{l}\text { Bilodeau, Soar and Cater-Steel (2010), Gouin- } \\
\text { Vallerand and De La Cruz (2013), Firnkorn and } \\
\text { Muller (2015) }\end{array}$ \\
\hline & \multirow[t]{2}{*}{ Freight (4) } & QAL & $\begin{array}{l}\text { Muñuzuri, Duin and Escudero (2010), Dablanc et al. } \\
\text { (2012), Ballantyne et al. (2013) }\end{array}$ \\
\hline & & QAN & Browne et al. (2010) \\
\hline \multirow{2}{*}{$\begin{array}{l}\text { Conceptual } \\
\text { framework }(2 ; \\
3 \%)\end{array}$} & People (2) & QAL & Batty et al. (2012), Piro et al. (2014) \\
\hline & Freight (0) & & \\
\hline
\end{tabular}

* The first number in brackets represents the number of papers, whereas the second the percentage on the total amount of papers (71).

** QAL: qualitative analyses; QAN: quantitative analyses

As shown in the rows in Table 1, a wide range of methods was used in the literature. Among these, the two most adopted ones were case study and simulation. The papers based on case studies (24) tackled the application of ITS solutions within the urban context. Oliveira, Nunes and Novaes (2010) and Ferrari et al. (2014) provided notable examples. In particular, the former presented a methodology to evaluate the viability of implementing intelligent delivery points in Brazil, analysing also the economic and the environmental impacts. The latter showed how smart card data could enable the accessibility of public transport systems for people with reduced mobility in London. The papers based on simulation (15) investigated how ITS 
solutions could impact on urban mobility, and quantified the effects in terms of costs, times, and/or environmental footprint. For example, Shin and Jun (2014) proposed a smart parking guidance algorithm to support drivers to find the most suitable parking facility in a city considering real-time occupancy. The other methods adopted by authors were analytical model (10 papers), survey (7), literature review (8), benchmarking (5) and conceptual framework (2). Analytical models were mainly used to quantitatively assess the benefits enabled by ITS in terms of KPIs (Key Performance Indicators, e.g. lead times, delivery delays) or, in a few cases, of economic returns. Surveys, instead, were mainly intended to investigate users' behaviours (e.g. drivers, citizens) or to depict an extensive overview of city strategies related to mobility. Literature reviews were mainly focused on freight transport. The authors usually analysed the state of the art in order to identify recent trends and research gaps: for example, Anand et al. (2012) provided a review of the main innovations regarding ITS technologies and policies. Some other authors focused on more specific subjects, e.g. ITS impacts on transport sustainability (Goldman and Gorham 2006). In the case of benchmarking, a collection of available data from ITS implementations was used to estimate the achievable benefits. Finally, a few authors attempted to develop conceptual frameworks (e.g. based on causal maps) related to the adoption of ITS solutions.

As expected, the research methods chosen by the authors depend on the objectives of their analyses. For example, analytical models were mainly used to provide quantitative tools that can be used in different contexts: the solution of a problem is reached through a well-defined, scientific and analytical calculation process. In a similar way, other authors developed simulation models to assess and predict the dynamic unfolding of events or processes, subsequent to the setting of certain parameters by the analysts. In most cases, both analytical models and simulations could be applied also in different application contexts than those for which they were firstly designed (e.g. it is possible to change some input data - like the size of the city, the type of vehicles, etc. - and calculate how the results vary). Instead, case studies or surveys were usually less generalisable, because of the specificity of the analysed cases.

The methods used by authors significantly differ based on the type of transport. On the one hand, ITS impact on people transport was investigated through a large variety of methods, with a slight preference for case studies (13) and simulations (10). On the other hand, case studies (11) and literature reviews (7) were the preferred methods for addressing the theme in freight transport. In addition, also the type of data analysis significantly varied depending on the 
research method used. 58\% of the 71 selected papers illustrated quantitative evidences. Specifically, papers based on literature reviews, conceptual frameworks and benchmarking methods typically introduced only qualitative results, whereas simulations and analytical models of course always introduced quantitative analyses. Instead, case studies and surveys can be both qualitative or quantitative: $52 \%$ of case studies and $57 \%$ of surveys reported quantitative outcomes. Obviously, the quantitative outcomes emerged from case studies differs significantly from those provided by analytical models and simulations. Case studies are empirical analyses which investigate contemporary phenomena in their real context (e.g. a parking lot, a road junction, a city), and the outcomes obtained are specific for that contexts, while the results achieved through analytical and simulation models are usually more general.

The analysis confirmed that the impact of ITS on both people and freight transport has not investigated in depth through an integrated approach yet. However, a certain number of authors (e.g. Kohler 2001; Patier 2002; Westerheim and Natvig 2008; Crainic, Gendreau and Potvin 2009; Ballantyne, Lindholm and Whiteing 2013) made a first attempt to summarise in a qualitative way the positive effects on citizens due to the adoption of ITS for freight transport. Indeed, vehicles dedicated to freight transport make a significant contribution to city congestion and environmental nuisances, such as emissions and noise, which impact adversely the quality of life in urban centres (Crainic, Gendreau and Potvin 2009).

\section{Summary of review: ITS for people and freight transport}

Papers are quite uniformly distributed between people (38 papers) and freight (33) transport.

\subsection{People transport}

The main application fields emerged from the literature related to people transport are Traffic management (13), Public transport (11), and Parking management (8). A few papers (6) do not focus on a specific application field, but analyse Smart Mobility in general. Results are summarised in Table 2. 
Table 2. People transport: classification of papers by Research Method and Application field

\begin{tabular}{|c|c|c|c|c|}
\hline & \multicolumn{4}{|c|}{ Application field } \\
\hline $\begin{array}{c}\text { Research } \\
\text { method }\end{array}$ & $\begin{array}{c}\text { Traffic } \\
\text { management }\end{array}$ & Public transport & $\begin{array}{c}\text { Parking } \\
\text { management }\end{array}$ & General \\
\hline $\begin{array}{l}\text { Literature } \\
\text { review }\end{array}$ & $\begin{array}{c}\text { Hancke, de Silva } \\
\text { and Hancke jr } \\
(2013)\end{array}$ & & & \\
\hline Simulation & $\begin{array}{l}\text { Salido, Peinado and } \\
\text { Giret (2011), Nha } \\
\text { et al. (2012), Barba } \\
\text { et al. (2012), } \\
\text { Galàn-Garcìa, } \\
\text { Venegas, and } \\
\text { Cielos (2014), } \\
\text { Poxrucker, Bahle } \\
\text { and Lukowicz } \\
\text { (2014) }\end{array}$ & $\begin{array}{l}\text { Cheng and Li } \\
\text { (2013) }\end{array}$ & $\begin{array}{c}\text { Geng and } \\
\text { Cassandras } \\
\text { (2012), Horng } \\
\text { (2014), Shin and } \\
\text { Jun (2014), } \\
\text { Caballero-Gil, C., } \\
\text { Molina-Gil and } \\
\text { Caballero-Gil, P. } \\
\text { (2015) }\end{array}$ & \\
\hline Case study & $\begin{array}{l}\text { Bhoraskar et al. } \\
\text { (2012), Smith et al. } \\
\text { (2013), Poslad et al. } \\
\text { (2015) }\end{array}$ & $\begin{array}{c}\text { Liu et al. (2009), } \\
\text { Fuller et al. (2012), } \\
\text { Das and Emuze } \\
\text { (2014), Ferrari et } \\
\text { al. (2014), Losa, } \\
\text { Pratelli and } \\
\text { Riccardi (2014), } \\
\text { Simonyi, Fazekas } \\
\text { and Gaspar (2014), } \\
\text { Khamitov } \\
\text { Iskakova, and } \\
\text { Khamitova (2015) }\end{array}$ & Ji et al. (2014) & $\begin{array}{l}\text { Moniri, Feld and } \\
\text { Muller (2012), } \\
\text { Marsal-Llacuna } \\
\text { Colomer-Llina`s } \\
\text { and Mele'ndez- } \\
\text { Frigola (2015) }\end{array}$ \\
\hline $\begin{array}{l}\text { Analytical } \\
\text { model }\end{array}$ & $\begin{array}{l}\text { Pérez et al. (2010), } \\
\text { Kolosz, Grant- } \\
\text { Muller and } \\
\text { Djemame (2013) }\end{array}$ & Gibson et al. (2015) & $\begin{array}{c}\text { Honarmand, } \\
\text { Zakariazadeh, and } \\
\text { Jadid (2014), } \\
\text { Zheng, } \\
\text { Rajasegarar and } \\
\text { Leckie (2015) }\end{array}$ & $\begin{array}{l}\text { Neirotti et al. } \\
\text { (2014) }\end{array}$ \\
\hline Benchmarking & & $\begin{array}{c}\text { Giffinger et al. } \\
\text { (2007), Debnath et } \\
\text { al. (2014) }\end{array}$ & & \\
\hline Survey & $\begin{array}{l}\text { Firnkorn and } \\
\text { Muller (2015) }\end{array}$ & & $\begin{array}{l}\text { Bilodeau, Soar } \\
\text { and Cater-Steel } \\
\text { (2010) }\end{array}$ & $\begin{array}{c}\text { Gouin- } \\
\text { Vallerand and } \\
\text { De La Cruz } \\
(2013) \\
\end{array}$ \\
\hline $\begin{array}{l}\text { Conceptual } \\
\text { framework }\end{array}$ & & & & $\begin{array}{c}\text { Batty et al. } \\
\text { (2012), Piro et } \\
\text { al. (2014) }\end{array}$ \\
\hline
\end{tabular}

\section{Traffic management}

Traffic control is one of the most important problems related to urban development. The majority of the papers considered the use of smart traffic lights, due to the critical role of road intersections affecting traffic conditions. Sensors are installed to detect different traffic 
variables (e.g. car speed, density, waiting time). Collected data are processed to give appropriate instructions to the traffic lights, thus helping reduce traffic congestions and allowing priority mechanisms for emergency vehicles like ambulances and fire trucks (Naga Raju, RajSekhar and Sandhya 2014). The key point is to enable flexibility in order to change from red to green in a faster or slower way depending on real time conditions (Galàn-Garcìa, Venegas, and Cielos 2014). Since the costs of installing these systems is high, in terms of both money and resources, it is crucial to assess the expected benefits within a city.

In the majority of the cases, papers were based on quantitative methods, primarily simulations, aiming to provide an assessment of the ITS-enabled impacts. For example, the goal of the simulation model developed by Nha, Djahel and Murphy (2012) was to assess the impact of providing drivers with information about traffic density and weather conditions. Galàn-Garcìa, Venegas, and Cielos (2014) presented a model that combines cellular automata and neural network theories to simulate car traffic in a motorway. A few authors resorted to case studies in order to investigate the benefits, also in terms of reduced pollution. For illustrative purposes, Smith et al. (2013) analysed the case of SURTRAC, a pilot implementation of an adaptive traffic signal control system installed for a nine-intersection road network in Pittsburgh, Pennsylvania (USA). The pilot test results demonstrated the effectiveness and potential of decentralised, adaptive traffic signal control in urban road networks. In comparison to the previous approach, which involved a combination of coordinated timing plans during rush periods and actuated free mode during non-rush periods, the SURTRAC system improved traffic flow efficiency by $25 \%-40 \%$ and reduced emissions by over $20 \%$.

\section{Public transport}

ITS solutions can support public transport in multiple ways, as shown by numerous projects already implemented worldwide (IoT Observatory 2012). The diffusion of ITS in this field gives the opportunity to investigate deployed solutions in depth. Indeed, case study and benchmarking are the most used methods, as reported in Table 2.

As far as case studies are concerned, Losa, Pratelli and Riccardi (2014) showed how a new ITSenabled public transport line could be fairly suited to the Italian context, and in particular to a medium sized city like Pisa, characterised by narrow streets, high density of buildings and need of sharing large part of bus paths in mixed traffic. Furthermore, this paper analysed a solution to solve the give-bus priority problem through Automatic Vehicle Location Systems (AVLS). 
The basic idea is to integrate the information of the bus (or tram) position into a traffic management system based on the use of smart traffic lights in order to give the priority to public transport. Buses are therefore detected before approaching an intersection, and green times are dynamically defined to provide the priority. By coordinating traffic signals at adjacent intersections, systems are able to optimise travel time by minimising the number of stops at intersections so that greater efficiency in traffic flow and reduced travel time and fuel consumption are achieved. With regard to public transport, the communication with final users proved to be a key issue. Simonyi, Fazekas and Gaspar (2014) performed a case study in Budapest (Hungary) and illustrated how the information collected from ITS solutions (e.g. waiting time, best transport solutions based on real-time location and traffic data) can be effectively communicated by using a smartphone application. With reference to benchmarking, Debnath et al. (2014) indicated London as the smartest city in the world for its public transport system, followed by Singapore and Paris. All buses in London were equipped with AVLS, onboard passenger information displays and announcement systems.

Despite their very low diffusion, a few notable contributions are based on quantitative models. In particular, Cheng and Li (2013) presented a simulation model named "Fuzzy Neural Network" to estimate the benefits achievable through AVLS. For example, in presence of public transports, the system decides which signal(s) and for how long should be red. Gibson (2015) presented an analytical model to estimate the time benefits, including the effects on travel time and access time, for the bus user. The user times decrease by $57 \%$, from $1028.3 \mathrm{~h} /$ day to 438.9 $\mathrm{h} /$ day. The increase in the off-peak demand has a strong positive effect on benefits in a range of $28-39 \%$. In contrast, the increase in the passenger renewal rate significantly reduces these benefits due to a higher access time loss.

\section{Parking management}

Parking is limited in almost every major city in the world leading to traffic congestion, air pollution, and driver frustration (Yan et al. 2011). On average, it takes 7.8 minutes to find an available parking space (Arnott, Rave and Schob 2005). This causes not only a waste of time and fuel for drivers looking for parking, but it also contributes to additional waste of time and fuel for other drivers as a result of traffic congestion (Geng and Cassandras, 2012). On a daily basis, it has been estimated that $30 \%$ of vehicles in the downtown area of major cities are cruising for a parking spot, with a consequent proportion of $\mathrm{CO}_{2}$ emissions (Arnott, Rave and Schob 2005; Hodel and Cong 2003). 
Generally, ITS applied to parking management results in the use of sensors, wireless communication technologies and smart applications to provide drivers with the information of free parking spots, thus decreasing drivers' frustration and negative impact on city traffic. The analysed papers mainly focused on the use of real-time variable message signs, such as directional arrows, names of the parking facilities, status, number of available parking spaces. As a matter of fact, during the past two decades traffic authorities in many cities started to adopt these solutions (Teodorovic and Lucic, 2003; Rodier and Shaheen, 2010). In some cases the opportunity of reserving a parking spot is also offered. Drivers access the central information system via smartphone or Internet to make the reservation. Then, different technologies can be used to recognise each car at entry points (e.g. RFId, Bluetooth) and to trigger automatic reservation checking and parking payment (Hodel and Cong, 2003). More recent papers investigated the opportunities enabled by Internet of Things (IoT) technologies for car parking systems (Ji et al. 2014). The car parking system was made up of three layers: sensors to detect the occupancy of individual parking spots, communication technologies to collect the information from sensors, and an application layer to give (near) real-time information to the drivers. The application layer is crucial to assure a good user experience. In this regard, Caballero-Gil, Molina-Gil and Caballero-Gil (2015) proposed a solution to predict location of the best available parking spots, consisting in a centralised system to predict free parking spaces and a low-cost mobile application to help the driver find the right spot.

As far as the research methods are concerned, simulations and analytical models to assess the quantitative benefits enabled by ITS solutions are diffused in the current literature. For example, Zheng, Rajasegarar and Leckie (2015) presented a prediction mechanism for parking occupancy in San Francisco and Melbourne based on real-time information (e.g. street name, side of street, arrival time, departure time, duration of parking events). Horng (2014) determined - though a simulation model - the nearest parking slot, and the current or opposite driving direction with the vehicle location information. By considering the driving direction, they could determine when the vehicles must turn around and thus reduce road congestion and speed up finding a parking space. The simulation results showed the strengths of the proposed smart parking mechanism in terms of avoiding congestions and decreasing the time to find a parking space. 
To have a clear overview of the drivers' behaviours, survey is a method that can be found in literature. In this regard, Bilodeau, Soar and Cater-Steel (2010) interviewed 133 randomly chosen drivers using a cluster sampling approach: survey questions focused on past and potential future parking experiences to help reduce any bias from creeping into the study.

\subsection{Freight Transport}

As cities are dominant centres of production and consumption, large movements of freight affect urban activities (Rodrigue, 2013). As a matter of fact, the number of freight vehicles moving within city limits is expected to continue to grow due to the current distribution practices based on low inventories and timely deliveries, and the growth of business-toconsumer electronic commerce that generates significant volumes of personal deliveries (eMarketer, 2013; International Transport Forum, 2012). Freight vehicles compete for the street and parking space capacity and contribute significantly to congestion and environmental nuisances, such as emissions and noise (OECD, 2003). These nuisances impact the life of people living or working in cities, and the productivity of the firms located in urban zones and of the associated supply chains (Benjelloun et al., 2008).

City Logistics aims to optimise the transport flows in an urban environment, and ITS is acknowledged as a fundamental component and enabling factor. The fundamental idea is to stop considering each shipment, company, and vehicle in isolation, but rather as components of an integrated logistics system to be optimised. Coordination and consolidation are at the basis of this idea. For example, the vehicle manufacturers have an indirect impact on urban freight transport through the design and technological innovation behind freight vehicles; the public transport operators have an influence on local authorities and have an indirect impact on urban freight transport due to potential conflicts between passenger and freight activities. Trade associations and commercial organisations could potentially affect urban freight transport operations through, for example, lobbying for a particular policy (Taniguchi, Thompson and Yamada 2001; Crainic, Gendreau and Potvin 2009; Ballantyne, Lindholm and Whiteing 2013).

Differently from those related to people transport, the papers dealing with ITS in freight transport do not focus on individual application fields (e.g. Traffic management, Parking management). Therefore, they were classified on the basis of the scope: most of them (20) analysed the implication of ITS only within an urban environment, whereas others (13) extended the scope of the analysis to the upstream supply chain, where multiple modes of 
transport are often available and decisions have usually consequences on last mile logistics. Table 3 summarises the results.

Table 3. Freight transport: classification of papers by Research Method and scope

\begin{tabular}{|c|c|c|}
\hline & \multicolumn{2}{|c|}{ Scope } \\
\hline $\begin{array}{l}\text { Research } \\
\text { method }\end{array}$ & $\begin{array}{l}\text { Focus only on city transport } \\
\text { (last mile logistics) }\end{array}$ & $\begin{array}{c}\text { Extension to the upstream supply } \\
\text { chain }\end{array}$ \\
\hline $\begin{array}{l}\text { Literature } \\
\text { review }\end{array}$ & $\begin{array}{c}\text { Goldman and Gorham (2006), } \\
\text { Benjelloun, Bigras and Crainic (2008), } \\
\text { Russo and Comi (2010) }\end{array}$ & $\begin{array}{l}\text { Behrends (2011), Perego, Perotti and } \\
\text { Mangiaracina (2011), Anand et al. } \\
\text { (2012), Mirzabeiki (2013) }\end{array}$ \\
\hline Simulation & $\begin{array}{c}\text { Aschauer and Starkl (2010), } \\
\text { Taniguchi, Thompson and Yamada } \\
\text { (2012), Gevaers, Van de Voorde and } \\
\text { Vanelslander (2014), Nechifor et al. } \\
\text { (2015) }\end{array}$ & Bhattacharya et al. (2014) \\
\hline Case study & $\begin{array}{c}\text { Oliveira, Nunes and Novaes (2010), } \\
\text { Van Duin, Quak and Muñuzuri (2010), } \\
\text { De Magalhães (2010), Diziain, } \\
\text { Taniguchi and Dablanc (2014), Van } \\
\text { Leeuwen, Van Eeden, and Ottenhof } \\
\text { (2014), Wang, Rodrigues and Evans } \\
\text { (2015) }\end{array}$ & $\begin{array}{c}\text { Westerheim and Natvig (2008), Kuse, } \\
\text { Endo and Ivao (2010), Reclus (2013), } \\
\text { De Souza et al. (2014), Oliveira et al. } \\
\text { (2015) }\end{array}$ \\
\hline $\begin{array}{l}\text { Analytical } \\
\text { model }\end{array}$ & $\begin{array}{l}\text { Gevaers, Van de Voorde and } \\
\text { Vanelslander (2011) }\end{array}$ & $\begin{array}{c}\text { Kayikci (2010), Joubert and Meintjes } \\
(2015)\end{array}$ \\
\hline Benchmarking & $\begin{array}{c}\text { Benjelloun, Crainic and Bigras (2010), } \\
\text { Taniguchi, Thompson and Yamada } \\
(2010)\end{array}$ & $\begin{array}{c}\text { Stapleton, Martinez and Van } \\
\text { Wassenhove (2009) }\end{array}$ \\
\hline Survey & $\begin{array}{l}\text { Browne et al. (2010), Muñuzuri, Duin } \\
\text { and Escudero (2010), Dablanc et al. } \\
\text { (2012), Ballantyne et al. (2013) }\end{array}$ & \\
\hline
\end{tabular}

The literature review highlighted several results. The majority of the papers concentrating on freight urban transport focused on case studies regarding specific cities (e.g. de Magalhaes, 2010; Westerheim and Natvig 2008). For example, Westerheim and Natvig (2008) analysed "SmartFreight", a project aiming to improve the freight distribution in cities through ITS based on open services, on-board equipment, and integrated wireless communication infrastructure. Reclus (2013) developed a system based on telematics intended to monitor, track and control the transport of dangerous goods in the Great Lyon urban area (France). Wang, Rodrigues and Evans (2015) empirically investigated how Information and Communication Technologies (ICTs) could contribute to reduce $\mathrm{CO}_{2}$ emissions in road freight transport adopting a multiple case study approach with three leading UK grocery retailers as exemplars of fast-moving consumer goods retailers. The results of the analysis showed that ICT solutions have a direct positive impact on $\mathrm{CO}_{2}$ emissions reduction, but there are further opportunities beyond 
retailers' own distribution networks. However, they are not fully exploited due to the retailers' reluctance to share information with competitors.

There is also an important amount of literature analyses. Anand et al. (2012) analysed the trends and the relevance of modelling research on city logistics and attempted to identify gaps in modelling urban freight domain. Other papers used surveys or simulations. Gevaers et al. (2014) investigated the main drivers that affect the B2c last mile delivery costs. The authors developed a tool to simulate these costs whereby last-mile characteristics were used as independent variables. The main factors considered were the consumer service level, the type of delivery, the market density/penetration, the type of delivery vehicles (and ITS adoption), and the environmental impact (e.g. due to packaging). For example, simulating a last mile delivery within a densely populated urban area $\left(>1,500\right.$ inhabitants $\left./ \mathrm{km}^{2}\right)$ or a rural area $(<50$ inhabitants $/ \mathrm{km}^{2}$ ) led to a cost difference of 5 euros/unit delivered (2.75 euros vs 7.75 euros respectively).

\section{Discussion: the main research gaps}

Although different studies have been conducted so far on ITS for people and freight transport in the urban context, and several facets have been deeply investigated, a number of topics are still under-represented or missing, as emerged from the reviewed literature. In order to provide some indications to address future research activities, we listed the main limitations emerged from the literature.

\section{Lack of up-to-date and complete literature reviews focused on ITS for urban mobility}

Although good pictures of the extant literature on ITS for urban mobility have been taken by several authors, these analyses are not up-to-date (all the 8 literature reviews were done before 2014) and complete (7 of 8 literature reviews focused only on ITS for freight transport, neglecting all the scientific papers based on issues and opportunities enabled by ITS technologies for people transport). In addition, the literature reviews examined in this study should better report possible classifications of papers on the basis of specific variables (e.g. areas of benefits, type of technology, type of stakeholder involved).

\section{Emphasis mainly on technology aspects, with limited attention being paid on value creation}

It can be observed that papers on ITS for urban mobility are mainly focused on technology aspects, neglecting value creation (e.g. cost-benefit analyses) or addressing the topic in a very 
marginal way. Although some impacts and benefits have been examined in terms of travel time reduction and environmental effects, there is still a general lack of quantitative models (i.e. only the $35 \%$ of papers reported a quantitative assessment) for measuring the overall impacts of ITS technologies in the urban context, and for splitting them among the several stakeholders involved.

\section{Lack of models / frameworks including both people and freight transport}

This analysis has confirmed that the impact of ITS on both people and freight transport has not investigated in depth through an integrated approach yet. Although a certain number of authors (e.g. Westerheim and Natvig 2008; Ballantyne, Lindholm and Whiteing 2013) made a first attempt to summarise in a qualitative way the positive effects on citizens due to the adoption of ITS for freight transport, a more comprehensive perspective is required to face the complexity of the entire problem. Indeed, vehicles dedicated to freight transport contribute significantly to city congestion and environmental nuisances, such as emissions and noise, which impact adversely the quality of life in urban centres (Crainic, Gendreau and Potvin 2009).

\section{Conclusions}

This paper investigated - through an in-depth literature review - the role of ITS for urban Smart Mobility, and illustrated the most diffused research methods to assess the benefits achievable by logistics operators, city governments and city users in the fields of people (Traffic management, Public transport and Parking management) and freight transport (City Logistics). The analysis focused on a set of 71 selected papers published from 2006 to 2014 and explored research methods, application fields and units of analysis.

In terms of the methods used, many of the papers examined present case studies (34\%) and simulations (21\%). Papers based on case studies aimed to study the application of ITS solutions within the urban context considering specific cities (e.g. London). Papers based on simulations investigated how ITS solutions impact on urban mobility and quantified the effects in terms of costs, times, and/or environmental footprint. It should be noted that the methods used by authors significantly differ based on the type of transport. On the one hand, ITS impact on people transport is investigated through a large variety of methods, with a slight preference for case studies (11) and simulations (9). Particularly, the areas of traffic management and parking 
management are mainly analysed through the use of simulations since the costs of installing these systems are high, and it is therefore important to assess the return on investments. ITS solutions can support public transport in multiple ways, as shown by numerous projects already implemented worldwide (IoT Observatory 2012). The diffusion of ITS in this field gives the opportunity to investigate deployed solutions in depth: indeed, case study and benchmarking are the most used methods. The same trend can be observed in freight transport, where the majority of the papers were focused on case studies regarding specific cities. Indeed, case study (11) is the most considered method that can be found in the literature.

This paper has both academic and practical/managerial implications. From an academic viewpoint, this study contributes to knowledge in this arena by providing a structured classification of the existing body of research on the role of ITS for urban Smart Mobility considering both people and freight transport. From a practical perspective, this paper contributes to the understanding of ITS solutions for urban Smart Mobility from different viewpoints. It provides practitioners with a full picture of the most important articles on this subject, including a classification intended to help them quickly find those papers they are interested in. The main beneficiaries of the results of this study are to be identified in both governments and logistics companies' managers interested in analysing the impact of ITS within the urban context.

This study has one potential limitation that should be noted. Although efforts were made to be all-inclusive, some studies could have been omitted from this review. Nonetheless, the authors are confident that the present review offers an accurate representation of the body of research on ITS for urban Smart Mobility published during the specified timeframe. The viewpoint adopted (i.e. aimed at providing a comprehensive and integrated vision on the topic) is particularly significant as it paves the way to the origination of a new stream of research where possible synergies between freight and people transport shall be investigated and exploited. This is recognised to be a critical issue by several authors (e.g. Kohler 2001; Patier 2002; Westerheim and Natvig 2008; Crainic, Gendreau and Potvin 2009; Ballantyne, Lindholm and Whiteing 2013), but a comprehensive analysis of ITS-enabled benefits, considering both freight and people transport within the city, has not been performed yet. For example, future research should investigate the benefits (e.g. reduction of urban traffic and bottlenecks) achievable by using ITS solutions to optimise freight urban transport. In this regard, a model aiming to 
quantify the ITS-enabled benefits (e.g. economic, environmental) - including the effects on people urban transport - is still missing. 


\section{References}

1. Ambrosini, C., and Routhier, J. 2004. "Objectives, methods and results of surveys carried out in the field of urban freight transport: An international comparison." Transport Reviews, 24 (1): 57-77.

2. Anand, N., Quak, H., van Duin, R., and Tavasszy, L. 2012. "City logistics modeling efforts: Trends and gaps-A review." Procedia - Social and Behavioral Sciences, 39: 101-115.

3. Arnott, R., Rave, T., and Schob. R. 2005. Alleviating Urban Traffic Congestion, MIT Press

4. Aschauer, G., and Starkl, F. 2010. "Time4trucks - cooperative time regulation of road freight transportation in urban areas for reducing bottlenecks." Procedia - Social and Behavioral Sciences, 2(3): 6242-6250.

5. Ballantyne, E., Lindholm, M., and Whiteing, A. 2013. "A comparative study of urban freight transport planning: addressing stakeholder needs." Journal of Transport Geography, 32: $93-101$.

6. Barba, C.T., Mateos, M.Á., Soto, P.R., Mezher, A.M., and Igartua, M.A. 2012. "Smart City for VANETs using warning messages, traffic statistics and intelligent traffic lights." Paper presented at IEEE Intelligent Vehicles Symposium, Proceedings, 902-907.

7. Batty, M., Axhausen, K. W., Giannotti, F., Pozdnoukhov, A., Bazzani, A., Wachowicz, M., and Portugali, Y. 2012. "Smart cities of the future." European Physical Journal Special Topics, 214 (1): 481.

8. Benjelloun, A., Bigras, Y., and Crainic, T.G. 2008. "Towards a Taxonomy of City Logistics" Paper presented at Systems, Publication CIRRELT, Interuniversity Research Center on Enterprise Networks, Logistics and Transportation, Université de Montréal.

9. Benjelloun, Y., Crainic, T.G., and A., Bigras, 2010. "Towards a Taxonomy of City Logistics Projects" Procedia: Social and Behavioral Sciences, 2 (3): 6217-6228.

10. Behrends, S. 2011. "Urban freight transport sustainability. The interaction of urban freight and intermodal transport." Thesis for the degree of doctor of philosophy, Chalmers University of Technology, Gothenburg.

11. Bhattacharya, A., Kumar, A., Tiwari, M.K., and Talluri, S. 2014. "An intermodal freight transport system for optimal supply chain logistics." Transportation Research Part C: Emerging Technologies, 3873-3884.

12. Bhoraskar, R., Vankadhara, N., Raman, B., and Kulkarni, P. 2012. "Wolverine: Traffic and road condition estimation using smartphone sensors". 4th International Conference on Communication Systems and Networks, COMSNETS 2012. 
13. Bilodeau, V., Soar, J., and Cater-Steel, A. 2010. Intelligent Parking Technologies - Do the Benefits Outweigh the Costs?, Kailua-Kona, Hawaii.

14. Browne, M., Allen, J., Steele, S., Cherrett, T., and McLeod, F. 2010. “Analysing the results of UK urban freight studies." Procedia: Social and Behavioral Sciences, 2 (3): 5956-5966.

15. Browne, M, and Allen, J. 2011. "Enhancing the sustainability of urban freight transport and logistics." Transport and Communications Bulletin for Asia and the Pacific, 80.

16. Bull, R. 2015. "ICT as an enabler for sustainable development: reflections on opportunities and barriers." Journal of Information, Communication and Ethics in Society, 13 (1): 19 23.

17. Caballero-Gil, C., Molina-Gil, J., and Caballero-Gil, P. 2015. "Low-cost service to predict and manage indoor parking spaces". 9th International Conference on Ubiquitous Computing and Ambient Intelligence, UCAmI 2015.

18. Carter, C.R., Kauffman, L., and Michel, A. 2007. "Behavioral supply management: a taxonomy of judgment and decision-making biases." International Journal of Physical Distribution and Logistics Management, 37 (8): 631-669.

19. Cheng, S.-T., and Li, J.-P. 2013. "The Adaptive Road Routing Recommendation for Traffic Congestion Avoidance in Smart City." Wireless Personal Communications, 77: 225-246.

20. Crainic, T. G., Gendreau, M., and Potvin, J.-Y. 2009. "Intelligent freight-transportation systems: Assessment and the contribution of operations research.” Transportation Research Part C: Emerging Technologies, 17 (6): 541-557.

21. Dablanc L., Genevieve G., Holliday, K., and Obrien, T. 2012. "Best Practices in Urban Freight Management: Lessons from an International Survey." TRB, Transportation Research Record (TRR), 29-38.

22. Das P., and Emuze, M. 2014. "Smart City perspectives of Bloemfontein, South Africa." Journal of Construction Project Management and Innovation, 4 (2): 930-949.

23. Debnath, A.K., Chin, H.C., Haque, M.M., and Yuen B. 2014. "A methodological framework for benchmarking smart transport cities." Cities, 37: 47-56.

24. De Magalhães, D.J. (2010). "Urban freight transport in a metropolitan context: The Belo Horizonte city case study." Procedia - Social and Behavioral Sciences, 2: 6076-6086.

25. De Souza, R., Gohb, M., Lauc, H.-C., Ngd, W.-S., and Tane, P.-S. 2014. "Collaborative Urban Logistics - Synchronizing the Last Mile.” Procedia - Social and Behavioral Sciences, 125: $422-431$.

26. Diziain, D., Taniguchi, E., and Dablanc, L. 2014. "Urban Logistics by Rail and Waterways in France and Japan." Procedia - Social and Behavioral Sciences, 125: 159 - 170. 
27. eMarketer (2013), "Worldwide B2c Ecommerce, 2013 Forecast and Comparative Estimates" [online], available at: http://www.emarketer.com (accessed 10 May 2015).

28. European Commission 2007. Green paper "Towards a new culture for urban mobility".

29. Ferrari, L., Berlingerio, M., Calabrese, and F., Reades, J. 2014. "Improving the Accessibility of Urban Transportation Networks for People with Disabilities." Transportation Research Part C: Emerging Technologies, 45: 27-40.

30. Firnkorn, J., and Muller, M. 2015. "Free-floating electric car sharing-fleets in smart cities: The dawning of a post-private car era in urban environments?" Environmental Science and Policy, 45: 30-40.

31. Fuller, D., Sahlqvist, S., Cummins, S. and Ogilvie, D. 2012. "The impact of public transportation strikes on use of a bicycle share program in London: Interrupted time series design." Preventive Medicine, 54: 74-76.

32. Galàn-García, J.L., Venegas, G., and Cielos, P. 2014. "An accelerated-time simulation for traffic flow in a Smart City." Journal of Computational and Applied Mathematics, 270: $557-563$.

33. Gevaers, R., Van de Voorde, E., and Vanelslander T., 2011. "Characteristics and typology of last-mile logistics from an innovation perspective in an urban context." City distribution and urban freight transport: multiples perspectives, Northampton, Edward Elgar Publishing: 56-71.

34. Gevaers, R., Van de Voorde, E., and Vanelslander T., 2014. "Cost Modelling and Simulation of Last-mile Characteristics in an Innovative B2C Supply Chain Environment with Implications on Urban Areas and Cities.” Procedia - Social and Behavioral Sciences, 125: $398-411$.

35. Geng, Y. and Cassandras, C.G. 2012. "Traffic light control using infinitesimal perturbation analysis.” 2012 IEEE 51st Annual Conference on Decision and Control (CDC).

36. Ghadge, A., Dani, S., and Kalawsky, R. 2012. "Supply chain risk management: present and future scope.” International Journal of Logistics Management, 23 (3): 313-339.

37. Gibson, J., Munizaga, M.A., Schneider, and C., Tirachini, A. 2015. "Estimating the bus user time benefits of implementing a median busway: Methodology and case study." Transportation Research Part A.

38. Giffinger, R., Fertner, C., Kramar, H., Kalasek, R., Pichler-Milanovic, N., and Meijers, E. 2007. "Smart Cities - Ranking of European medium-sized cities." Vienna University of Technology. 
39. Goldman, T., and Gorham, R. 2006. "Sustainable urban transport: Four innovative directions." Technology in Society, 28: 261-273.

40. Gouin-Vallerand, C. and De La Cruz, J. 2013. "Analysis of a context-aware recommender system model for smart urban environment.” Proceedings of International Conference on Advances in Mobile Computing and Multimedia, 13.

41. Hancke, G. P., de Silva, B. D. C., and Hancke, G. P. jr 2013. "The role of advanced sensing in smart cities." Sensors, 13.

42. Hodel, T.B. and Cong, S. 2003. "Parking space optimization services, a uniformed web application architecture.” ITS World Congress Proceedings, 16-20.

43. Holguín-Veras 2000. "A framework for an integrative freight market simulation." 2000 IEEE Intelligent Transportation Systems, 2000. Proceedings, 476-481.

44. Honarmand, M., Zakariazadeh, A., and Jadid, S. 2014. "Optimal scheduling of electric vehicles in an intelligent parking lot considering vehicle-to-grid concept and battery condition." Energy, 65: 572-579.

45. Horng, G.-J. 2014. "Using Cellular Automata for Parking Reccomendations in Smart Environments." PLoS ONE, 9 (8).

46. International Transport Forum 2012. Transport Outlook Seamless Transport for Greener Growth.

47. IoT Observatory 2012. Internet of Things: Smart Present or Smart Future?

48. ITS Handbook 2012. What are Intelligent Transport Systems?

49. Ji, Z., Ganchev, I., O’Droma, M., Zhao, L., and Zhang, L. 2014. “A Cloud-Based Car Parking Middleware for IoT-Based Smart Cities: Design and Implementation." Sensors, 14, 22372-22393.

50. Johnson, B. 2008. “Cities, systems of innovation and economic development." Innovation: Management, Policy and Practice, 10 (2-3): 146-155.

51. Joubert, J. W., and Meintjes, S. 2015. "Repeatability \& reproducibility: Implications of using GPS data for freight activity chains". Transportation Research Part B, 76: 81-92.

52. Kayikci, Y. 2010. "A conceptual model for intermodal freight logistics center location decisions." Procedia - Social and Behavioral Sciences, 2: 6297-6311.

53. Khamitov, A.N., Iskakova, Z.D., and Khamitova, G.D. 2015. "Analysis of framework for building a smart city through the implementation of a smart bus stop project." Actual Problems of Economics, 166 (4): 462-469.

54. Kohler, U. 2001. "How to change urban traffic with city logistics." Control in Transportation Systems 2000 - Proceedings 9th IFAC Symposium, Braunschweig, 
Germany, 1: 199-201.

55. Kolosz, B.W., Grant-Muller, S.M., and Djemame, K. 2013. "Modelling uncertainty in the sustainability of Intelligent Transport Systems for highways using probabilistic data fusion." Environmental Modelling and Software, 49: 78-97.

56. Kolosz, B.W., Grant-Muller, S.M., and Djemame, K. 2014. “A Macroscopic Forecasting Framework for Estimating Socio-economic and Environmental Performance of Intelligent Transport Highways." IEEE Transactions on Intelligent Transport Systems, 15(2): 723-736.

57. Kuse, H., Endo, A., and Iwao, E. 2010. "Logistics facility, road network and district planning: Establishing comprehensive planning for city logistics." Procedia - Social and Behavioral Sciences, 2 (3), 6251-6263.

58. Liu, L., Hou, A., Biderman, A., Ratti, C., and Chen, J. 2009. "Understanding individual and collective mobility patterns from smart card records: a case study in Shenzhen." Proceedings of the 12th International IEEE Conference on Intelligent Transportation Systems, St. Louis, MO, USA.

59. Losa M., Pratelli, A., and Riccardi, C. 2014. "The integration of buses with a high level of service in the medium cities urban context". WIT Transactions on the Built Environment, 138: $161-172$.

60. Mangiaracina, R., Marchet, G., Perotti, S. and Tumino, A. 2015. "A review of the environmental implications of B2C e-commerce: a logistics perspective.” International Journal of Physical Distribution and Logistics Management, 45 (6): 565-591.

61. Marsal-Llacuna M.L., Colomer-Llina`s J., and Mele'ndez-Frigola J. 2015. "Lessons in urban monitoring taken from sustainable and livable cities to better address the Smart Cities initiative." Technological Forecasting and Social Change.

62. Meixell, M.J., and Norbis, M. 2008. "A review of the transportation mode choice and carrier selection literature.” International Journal of Logistics Management, 19 (2): 183-211.

63. Mendoza, A., and Garcìa, A. 2000. "Potential applications of intelligent transportation systems to road freight transport in Mexico.” Transportation Research Records, 1707: 8185.

64. Miles, J.C. 2014. "Intelligent Transport Systems: Overview and Structure (History, Applications, and Architectures).” Encyclopedia of Automotive Engineering.

65. Mirzabeiki, V. 2013. "An overview of freight intelligent transportation systems." International Journal of Logistics Systems and Management, 14 (4): 473-489. 
66. Moniri, M.M., Feld, M., and Muller, C. 2012. "Personalized In-Vehicle Information Systems: Building an Application Infrastructure for Smart Cars in Smart Spaces.” 2012 Eighth International Conference on Intelligent Environments.

67. Muñuzuri, J., van Duin, J.H.R., and Escudero, A. 2010. "How efficient is city logistics? Estimating ecological footprints for urban freight deliveries." Procedia - Social and Behavioral Sciences, 2: 6165-6176.

68. Naga Raju, T., RajSekhar, K., and Sandhya, V. 2014. "Smart Traffic Light Control System for Emergency and Detection of Stolen Vehicles." International Journal of Advanced Research in Science, Engineering and Technology, 1 (5).

69. Nechifor, S., Puiu, D., Târnaucă, B., and Moldoveanu, F. 2015. “Autonomic aspects of IoT based systems: A logistics domain scheduling example." International Workshop on Interoperability and Open-Source Solutions for the Internet of Things, 9001: 153-168.

70. Neirotti, P., De Marco, A., Cagliano, A. C., Mangano, G., and Scorrano, F. 2014. "Current trends in smart city initiatives: Some stylised facts." Cities, 38: 25-36.

71. Ngoc Nha, V. T., Djahel, S., and Murphy J. 2012. "A Comparative Study of Vehicles' Routing Algorithms for Route Planning in Smart Cities." VTM 2012, Satellite Workshop..

72. Nielsen, D.L., Jespersen, P.H., Petersen, T. and Hansen, L.G. 2003. "Freight transport growth-a theoretical and methodological framework." European Journal of Operational Research, 144: 295-305.

73. OECD 2003. "OECD Environmental Indicators: development, measurement and use." Work, 25 (0): 37.

74. Oliveira, L. K., Nunes, N. T. R., and Novaes, A. G. N. 2010. “Assessing model for adoption of new logistical services: An application for small orders of goods distribution in Brazil." Procedia - Social and Behavioral Sciences, 2 (3): 6286-6296.

75. Oliveira, R. R., Cardoso, I. M. G., Barbosa, J. L. V., da Costa, C. A., and Prado, M. P. 2015. "An intelligent model for logistics management based on geofencing algorithms and RFID technology". Expert Systems with Applications, 42 (15-16): 6082-6097.

76. Patier, D. 2002. La logistique dans la ville. CELSE Editeur, Paris.

77. Perakovic, D. 2014. "IoT infrastructure as a basis for new information services in the ITS environment." 22nd Telecommunications forum TELFOR.

78. Perego, A., Perotti, S., and Mangiaracina, R. 2011. "ICT for logistics and freight transportation: A literature review and research agenda. " International Journal of Physical Distribution and Logistics Management, 41 (5): 457-483. 
79. Pérez, J., Seco, F, Milanes, V., Jimenez, A., Diaz, J., and de Pedro, T. 2010. “An RFIDbased intelligent vehicle speed controller using active traffic signals." Sensors, 10 (6): $5872-5887$.

80. Piro, G., Cianci, I., Grieco, L., Boggia, G., and Camarda P. 2014. "Information centric services in Smart Cities.” Journal of Systems and Software, 88: 169-188.

81. Poslad, S., Ma, A., Wang, Z., and Mei, H. 2015. "Using a Smart City IoT to Incentivise and Target Shifts in Mobility Behaviour - Is It a Piece of Pie?" Sensors, 15: 13069-13096.

82. Poxrucker, A., Bahle, G., and Lukowicz, P. 2014. "Towards a Real-world Simulator for Collaborative Distributed Learning in the Scenario of Urban Mobility.” 2014 IEEE Eighth International Conference on Self-Adaptive and Self-Organizing Systems Workshops.

83. Reclus, F. 2013. "Monitoring, control and management of dangerous goods transports in urban areas". 20th ITS World Congress Tokyo 2013.

84. Regan A., and Garrido, R. 2001. Modelling freight demand and shipper behaviour: State of the art, future directions. In: Hensher D, editor. Travel Behaviour Research. PergamonElsevier Science.

85. Rodier, C.J., and Shaheen. S.A. 2010. "Transit-based smart parking: An evaluation of the San Francisco bay area field test.” Transportation Research Part C, 18: 225-233.

86. Rodrigue, J.P. 2013. The geography of Transportation Systems. New York: Routledge.

87. Russo, F., and Comi, A. 2010. "A model system for the ex-ante assessment of city logistics measures." Research in Transportation Economics, 31 (1): 81-87.

88. Salido, A., Peinado, M., and Giret, A. 2011. "A holonic simulation environment for smart transportation systems.” International Journal of Production Research. 49 (5) 1425-1439.

89. Seuring, S., and Gold, S. 2012. "Conducting content-analysis based literature reviews in supply chain management." Supply Chain Management: An International Journal, 17 (5): 544-555.

90. Shin, J.-H. and Jun, H.-B. 2014. "A study on smart parking guidance algorithm." Transportation Research Part C: Emerging Technologies, 44: 299-317.

91. Simonyi, E., Fazekas, Z., and Gaspar, P. 2014. "Smartphone application for assessing various aspects of Urban public transport". Transportation Research Procedia, 3: 185-194.

92. Smith, S.F., Barlow, G.J., Xie, X.F., and Rubinstein, Z.B. 2013. "Smart urban signal networks: initial application of the SURTRAC adaptive traffic signal control system." Proceedings of the Twenty-Third International Conference on Automated Planning and Scheduling, Rome, Italy.

93. Srivastava, S.K. 2007. "Green supply-chain management: a state-of-the-art literature 
review." International Journal of Management Reviews, 9 (1): 53-80.

94. Stapleton, O., Martinez, A.P., and Van Wassenhove, L.N. 2009. Last Mile Vehicle Supply Chain in the International Federation of Red Cross and Red Crescent Societies.

95. Taniguchi, E., Thompson, R.G., and Yamada, T. 2001. City Logistics: Network Modelling and Intelligent Transport Systems.

96. Taniguchi, E., Thompson, R.G., and Yamada, T. 2010. "Emerging techniques for enhancing the practical application of city logistics models." Procedia - Social and Behavioral Sciences, 2: 5899-5910.

97. Taniguchi, E., Thompson, R.G., and Yamada, T. 2012. "Incorporating risks in City Logistics." Procedia - Social and Behavioral Sciences, 39: 3-18.

98. Teodorovic, D. and Lucic, P. 2003. Parking space inventory control: an artificial intelligence approach.

99. United Nations 2014. "Human Development Report 2014." Sustaining Human Progress: Reducing Vulnerabilities and Building Resilience.

100. Van Duin, J.H.R., Quak, H., and Muñuzuri, J. 2010. "New challenges for urban consolidation centres: A case study in The Hague." Procedia-Social and Behavioral Sciences, 2 (3): 6177-6188.

101. Van Leeuwen, D., Van Eeden, K., and Ottenhof, F. 2014. "The digital road authority: Reduction of emissions in city centres by optimisation of freight traffic." 21st World Congress on Intelligent Transport Systems, ITSWC 2014: Reinventing Transportation in Our Connected World.

102. Wang, Y., Rodrigues, V.S., and Evans, L. 2015. "The use of ICT in road freight transport for $\mathrm{CO} 2$ reduction - An exploratory study of UK's grocery retail industry." International Journal of Logistics Management, 26 (1): 2-29.

103. Westerheim, H., and Natvig, M.K. 2008. "Smart freight transport in urban areas the 'smartfreight' project." 15th World Congress on Intelligent Transport Systems and ITS America Annual Meeting 2008. 8: 5588-5591.

104. Yan, G., Yang, W., Rawat, D. B., and Olariu, S. 2011. "SmartParking: A secure and intelligent parking system.” IEEE Intelligent Transportation Systems Magazine, 3 (1): 1830.

105. Zheng, Y., Rajasegarar, S., and Leckie, C. 2015. "Parking Availability Prediction for Sensor-Enabled Car Parks in Smart Cities.” 2015 IEEE Tenth International Conference on Intelligent Sensors, Sensor Networks and Information Processing (ISSNIP). 